\title{
Spatial and Temporal Variations of Extreme Climate Events in Xinjiang, China during 1961-2010
}

\author{
Xiangling Tang1* ${ }^{*}$ Xin $\mathrm{Lv}^{2}$, Yineng Ouyang ${ }^{3}$ \\ ${ }^{1}$ Geography Department, Natural Science of Shihezi University, Shihezi, China \\ ${ }^{2}$ Production and Construction Corps, Xinjiang Key Laboratory of Oasis Ecological Agriculture, Shihezi, China \\ ${ }^{3}$ College of Science, Shihezi University, Shihezi, China \\ Email: "txl_tea@126.com
}

Received 19 March 2016; accepted 15 August 2016; published 18 August 2016

Copyright (C) 2016 by authors and Scientific Research Publishing Inc.

This work is licensed under the Creative Commons Attribution International License (CC BY). http://creativecommons.org/licenses/by/4.0/

(c) (i) Open Access

\begin{abstract}
Daily maximum/minimum temperature and precipitation data from 35 weather stations in Xinjiang during 1961-2010 were examined using kriging spatial analysis, linear tendency estimation, and correlation analysis. Temporal trends and spatial distribution patterns of extreme temperature and precipitation in this area were then analyzed using 12 extreme temperature and 7 extreme precipitation indices. The following results were obtained. 1) Over the past 50 years, extreme cold indices, excepting the monthly maximum temperature minimum value and monthly extreme minimum temperature, showed slight decreasing trends. These indices include the maximum number of consecutive frost days, icy days, cold-nighttime days, and cold-daytime days. 2) Extreme warm events generally showed significant increasing trends $(P<0.01)$, including the indices of summertime days, warm-nighttime days, warm-daytime days, monthly extreme maximum temperature, and monthly minimum temperature maximum value. 3) The spatial distributions of threshold values of extreme warm and cold events showed notable regional differences. A reducing trend of extreme cold events and an increase in extreme warm events has occurred mainly in northern Xinjiang. 4) For the past 50 years, six extreme precipitation indices, aside from consecutive dry days, showed significant increasing trends in Xinjiang $(P<0.05)$ and notable differences in spatial distribution. The increase in extreme precipitation events was more rapid at northern than at southern sites. Extreme precipitation intensity was greater in mountainous areas, and precipitation frequency increased in the plain region. 5) Factor analysis revealed good correlations among extreme temperature indices, excepting extreme temperature days.
\end{abstract}

\section{Keywords}

Xinjiang Area, Extreme Climatic Event, Spatial Change

\footnotetext{
${ }^{*}$ Corresponding author.
}

How to cite this paper: Tang, X.L., Lv, X. and Ouyang, Y.N. (2016) Spatial and Temporal Variations of Extreme Climate Events in Xinjiang, China during 1961-2010. American Journal of Climate Change, 5, 360-372. 


\section{Introduction}

At present, no doubt exists about global warming. The fourth assessment report of the Intergovernmental Panel on Climate Change [1] identified a warming trend of $0.13^{\circ} \mathrm{C} / 10 \mathrm{a}$ over the past 50 years. The warming trend in China has been $0.22^{\circ} \mathrm{C} / 10 \mathrm{a}$ [2], with significant increases in annual mean temperature and heating rate [3]. The increasing mean temperature not only affects the change in extreme temperature values, but can also leads to extreme climatic events, such as heat waves and rainstorms, which show trends of increasing frequency, strength, and intensity [4].

Many studies have indicated that frequent extreme climatic events cause huge losses for society and the economy, as well as loss of human lives [5]. The most recent statistics reveal an increase of up to 10-fold in the economic loss arising from global climatic change and related extreme climatic events over the past 40 years. In China, weather disasters caused by extreme climatic events account for $70 \%$ of all natural hazards [6]. Hence, extreme climatic events are sources of widespread concern for governments and researchers [7] [8]. Studies of changes in these events are necessary not only to guarantee state security and economic development, but also to prevent disasters, reduce damage-related needs, and, most importantly, safeguard people's safety and livelihoods.

Xinjiang, located far from the ocean in the center of Eurasia, in the border region of northwestern China, is impacted by the uplifted Tibetan Plateau, westerly wind circulation effects, and high mountain landforms. This region is thus an important route by which cold air invades China, and has a diverse climate. Northern Xinjiang has a variable continental arid and semi-arid climate, whereas southern Xinjiang has a warm continental arid climate; the ecology of these regions is fragile and has suffered greatly under the influence of climatic change [9]-[12]. In recent years, large studies have investigated the spatial and temporal distribution of and variation in extreme precipitation in Xinjiang [13]. These studies are of great importance for attaining a correct understanding of climatic variation in this region. However, most previous studies have considered single meteorological elements, such as temperature or precipitation in southern or northern Xinjiang, and discrepancies exist in the length of time represented by meteorological data and stations from which they were collected. Hence, this study was conducted using internationally recognized extreme climatic indices to examine long-term trends of change in extreme climatic events and their spatial distribution patterns, as well as problems existing in the whole of Xinjiang that have actual reference value for economic development and response to climatic disasters in the future.

\section{Research Data and Methods}

\subsection{Research Data Source and Treatment}

Daily precipitation and maximum, minimum, and mean temperature data from China's Meteorological Administration for the period 1961-2010 in Xinjiang were used for this study. Data from 43 meteorological stations were reviewed to identify problems with missing or misdetected observations. We selected high-quality data from 35 stations (Table 1, Figure 1) as the study target. For missing and misdetected data from stations with less complete records, we used corrected data from Bai Lei et al. [14].

\subsection{Study Method}

The standards used to define and calculate the extreme climatic indices used in this study were based on the World Meteorological Organization's Commission for Climatology World Climate Research and Climatic Variation and Predictability programs' expert team on climate change detection, monitoring, and indices [15]. This methodology has been applied to many countries and regions [16], including Xinjiang. Using RClimDex software (http://cccma.seos.uvic.ca/ETCCDMI/), 19 extreme climatic indices (7 related to precipitation and 12 related to temperature) were developed and applied (Table 2).

All of the extreme climate indices reflect three aspects of temperature or precipitation events: strength, frequency, and temporal duration of climatic change. In extreme climate research, a certain percentile value is usually adopted as a threshold (with values exceeding it defined as extreme), and calculations are performed according to the nonparametric method of Bonsal et al. [17], as follows: for a meteorological factor with $N$ values, these values are sorted in ascending order $\left(X_{1}, X_{2}, \ldots, X_{m}, \ldots, X_{N}\right)$; the probability that a certain value is less than or equal to the rank of $X_{m}$ is then $P=(m-0.31) /(N+0.38)$, where $P$ denotes percentile, $m$ is the serial number 
of $X_{m}$, and $N$ is the number of meteorological values.

In this study, percentile values were used to calculate relative and other indices. Specifically, temperature data were sorted in ascending order, and the $90^{\text {th }}$ and $10^{\text {th }}$ percentile values were regarded as thresholds for extreme temperature. When the highest temperature on a given day exceeded the $90^{\text {th }}$ percentile value, an extreme high-temperature event was considered to have occurred on that day; when the highest temperature on a given day was less than the $10^{\text {th }}$ percentile value, an extreme low-temperature event was considered to have occurred. Secondly, we analyzed extreme climatic events using linear tendency estimation, the Mann-Kendall method, and the kriging method of spatial analysis.

Table 1. Site meteorological information in the study area.

\begin{tabular}{|c|c|c|c|c|c|}
\hline No. & Station & Longitude $\left({ }^{\circ} \mathrm{E}\right)$ & Latitude $\left({ }^{\circ} \mathrm{N}\right)$ & Elevation (m) & Period of series \\
\hline 1 & Habahe & 86.40 & 48.05 & 532.6 & 1961.01.01-2010.12.31 \\
\hline 2 & Jimunai & 85.87 & 47.43 & 984.1 & 1961.01.01-2010.12.31 \\
\hline 3 & Fuai & 87.47 & 47.12 & 500.9 & 1961.01.01-2010.12.31 \\
\hline 4 & Aletai & 88.08 & 47.73 & 735.3 & 1961.01.01-2010.12.31 \\
\hline 5 & Fuyun & 89.52 & 46.98 & 807.5 & 1961.01.01-2010.12.31 \\
\hline 6 & Qinghe & 90.38 & 46.67 & 1218.2 & 1961.01.01-2010.12.31 \\
\hline 7 & Alashankou & 82.57 & 45.18 & 336.1 & 1961.01.01-2010.12.31 \\
\hline 8 & Tuoli & 83.60 & 45.93 & 1077.8 & 1961.01.01-2010.12.31 \\
\hline 9 & Beitashan & 90.53 & 45.37 & 1653.7 & 1961.01.01-2010.12.31 \\
\hline 10 & Caijiahu & 87.53 & 44.20 & 440.5 & 1961.01.01-2010.12.31 \\
\hline 11 & Qitai & 89.57 & 44.02 & 793.5 & 1961.01.01-2010.12.31 \\
\hline 12 & Yinning & 81.33 & 43.95 & 662.5 & 1961.01.01-2010.12.31 \\
\hline 13 & Zhaosu & 81.13 & 43.15 & 1851.0 & 1961.01.01-2010.12.31 \\
\hline 14 & Baluntai & 86.30 & 42.73 & 1739.0 & 1961.01.01-2010.12.31 \\
\hline 15 & Kumishi & 88.22 & 42.23 & 922.4 & 1961.01.01-2010.12.31 \\
\hline 16 & Bayinbuluke & 84.15 & 43.03 & 2458.0 & 1961.01.01-2010.12.31 \\
\hline 17 & Tulufan & 89.20 & 42.93 & 34.5 & 1961.01.01-2010.12.31 \\
\hline 18 & Akesu & 80.23 & 41.17 & 1103.8 & 1961.01.01-2010.12.31 \\
\hline 19 & Baicheng & 81.90 & 41.78 & 1229.2 & 1961.01.01-2010.12.31 \\
\hline 20 & Luntai & 84.25 & 41.78 & 976.1 & 1961.01.01-2010.12.31 \\
\hline 21 & Kuerle & 86.13 & 41.75 & 931.5 & 1961.01.01-2010.12.31 \\
\hline 22 & Tuergate & 75.40 & 40.52 & 3504.4 & 1961.01.01-2010.12.31 \\
\hline 23 & Wuqia & 75.25 & 39.72 & 2175.7 & 1961.01.01-2010.12.31 \\
\hline 24 & Kashi & 75.98 & 39.47 & 1289.4 & 1961.01.01-2010.12.31 \\
\hline 25 & Aheqi & 78.45 & 40.93 & 1984.9 & 1961.01.01-2010.12.31 \\
\hline 26 & Alaer & 81.27 & 40.55 & 1012.2 & 1961.01.01-2010.12.31 \\
\hline 27 & Ruoqiang & 88.17 & 39.03 & 887.7 & 1961.01.01-2010.12.31 \\
\hline 28 & Shache & 77.27 & 38.43 & 1231.2 & 1961.01.01-2010.12.31 \\
\hline 29 & Pishan & 78.28 & 37.62 & 1375.4 & 1961.01.01-2010.12.31 \\
\hline 30 & Hetian & 79.93 & 37.13 & 1375.0 & 1961.01.01-2010.12.31 \\
\hline 31 & Minfeng & 82.72 & 37.07 & 1409.5 & 1961.01.01-2010.12.31 \\
\hline 32 & Qiemo & 85.55 & 38.15 & 1247.2 & 1961.01.01-2010.12.31 \\
\hline 33 & Balikun & 93.00 & 43.60 & 1677.2 & 1961.01.01-2010.12.31 \\
\hline 34 & Yiwu & 94.70 & 43.27 & 1728.6 & 1961.01.01-2010.12.31 \\
\hline 35 & Hongliuhe & 94.67 & 41.53 & 1573.8 & 1961.01.01-2010.12.31 \\
\hline
\end{tabular}




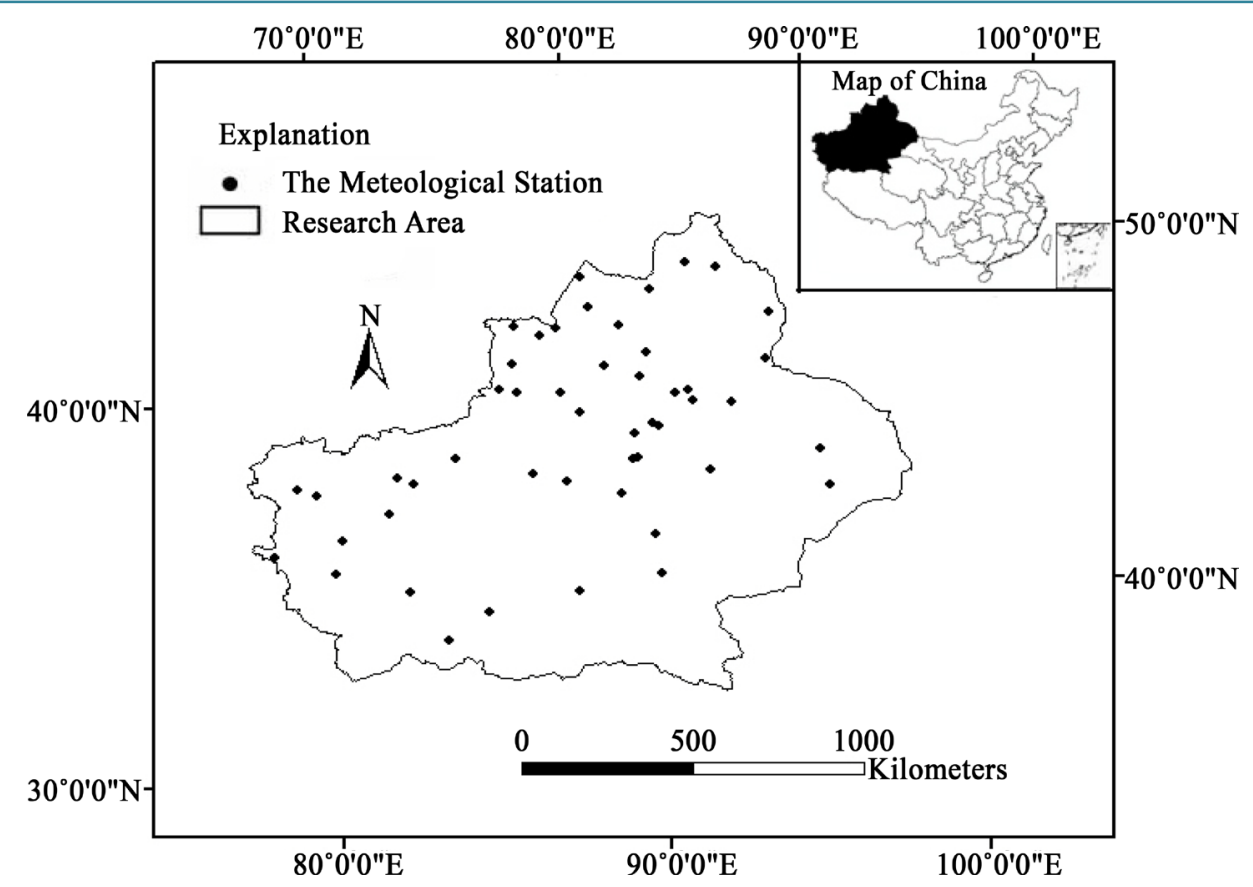

Figure 1. Distribution of meteorological stations in Xinjiang.

Table 2. Definition of extreme temperature and precipitation indices.

\begin{tabular}{|c|c|c|c|c|}
\hline & Index & Descriptive name & Definition & Unit \\
\hline \multirow{12}{*}{ Temperature } & TXx & Warmest day & Annual highest TX & ${ }^{\circ} \mathrm{C}$ \\
\hline & $\mathrm{TNx}$ & Warmest night & Annual highest TN & ${ }^{\circ} \mathrm{C}$ \\
\hline & TXn & Coldest day & Annual lowest TX & ${ }^{\circ} \mathrm{C}$ \\
\hline & TNn & Coldest night & Annual lowest TN & ${ }^{\circ} \mathrm{C}$ \\
\hline & TN10p & Cold night frequency & Percentage of days when $\mathrm{TN}<10^{\text {th }}$ percentile of $1961-1990$ & $\mathrm{~d}$ \\
\hline & TX10p & Cold day frequency & Percentage of days when $\mathrm{TX}<10^{\text {th }}$ percentile of $1961-1990$ & $\mathrm{~d}$ \\
\hline & TN90p & Warm night frequency & Percentage of days when $\mathrm{TN}>90^{\text {th }}$ percentile of $1961-1990$ & $\mathrm{~d}$ \\
\hline & TX90p & Warm day frequency & Percentage of days when $\mathrm{TX}>90^{\text {th }}$ percentile of $1961-1990$ & $\mathrm{~d}$ \\
\hline & FD & Frost days & Annual count when $\mathrm{TN}<0^{\circ} \mathrm{C}$ & $\mathrm{d}$ \\
\hline & ID & Ice days & Annual count when $\mathrm{TX}<0^{\circ} \mathrm{C}$ & $\mathrm{d}$ \\
\hline & SU25 & Summer days & the highest temperature is over $25^{\circ} \mathrm{C}$ day number & $\mathrm{d}$ \\
\hline & DTR & Diurnal temperature range & Annual mean difference between TX and TN & ${ }^{\circ} \mathrm{C}$ \\
\hline \multirow{7}{*}{ Precipitation } & SDII & Simple daily intensity index & Average precipitation on wet days & $\mathrm{Mm} / \mathrm{d}$ \\
\hline & PRCPTOT & Wet day precipitation & Annual total precipitation from wet days & $\mathrm{mm}$ \\
\hline & RX1day & Maximum 1-day precipitation & Annual maximum 1-day precipitation & $\mathrm{mm}$ \\
\hline & RX5day & Maximum 5-day precipitation & Annual maximum consecutive 5-day precipitation & $\mathrm{mm}$ \\
\hline & CDD & Consecutive dry days & Maximum number of consecutive dry days & d \\
\hline & CWD & Consecutive wet days & Maximum number of consecutive wet days & $\mathrm{d}$ \\
\hline & R95p & Very wet day precipitation & $\begin{array}{l}\text { Annual total precipitation when } \mathrm{RR}>95^{\text {th }} \text { percentile of } \\
1961-1990 \text { daily precipitation }\end{array}$ & $\mathrm{mm}$ \\
\hline
\end{tabular}

Notes: ${ }^{a}$ All the indices are calculated by RCLimDEX. Abbreviations are as follows: TX, daily maximum temperature; TN, daily minimum temperature; TG, daily mean temperature; RR, daily precipitation. A wet day is defined when $R R \geq 0.1 \mathrm{~mm}$, and a dry day is defined when RR $<0.1 \mathrm{~mm}$. Indices are included for completeness but are not analyzed further in this article. 


\section{Changes in Extreme Temperature Events in Xinjiang over the Past 50 Years}

\subsection{Interannual Variation in Extreme Cold Events}

Consistent with global changes, the frequency of extreme low-temperature events in the Xinjiang area was found to have decreased while that of extreme high-temperature events increased [18]. Linear variation in extreme cold indices in Xinjiang over the past 50 years generally showed a decreasing curvilinear trend (Figure 2). The interannual variation tendency rates for the maximum numbers of continuous frost days (FDs), icy days (IDs), cold-nighttime days (TN10p), and cold-daytime days (TX10p) were $-4.8 \mathrm{~d} / 10 \mathrm{a},-2.75 \mathrm{~d} / 10 \mathrm{a},-2.24 \mathrm{~d} / 10 \mathrm{a}$, and $-0.88 \mathrm{~d} / 10 \mathrm{a}$, respectively (all $\alpha \leq 0.01$ ), and their correlation coefficients by year were $-0.774,-0.475$, -0.827 , and -0.39 , respectively (Table 3 ).
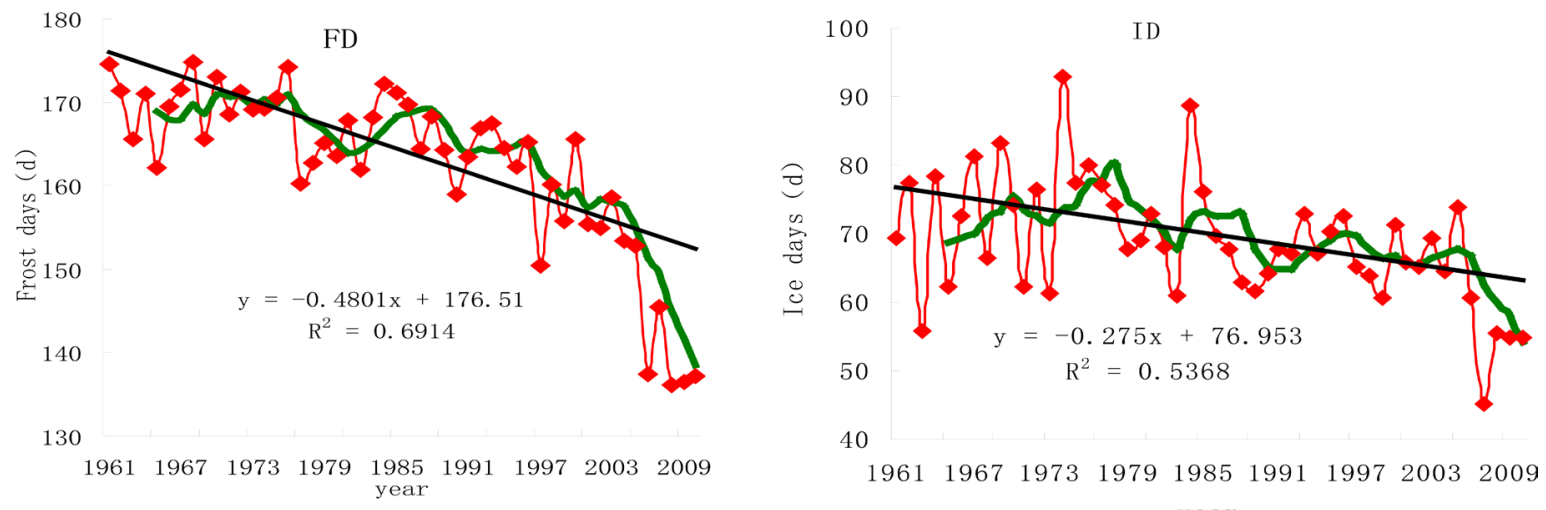

40

$19611967 \quad 1973 \quad 197919851991 \quad 19972003 \quad 2009$ year
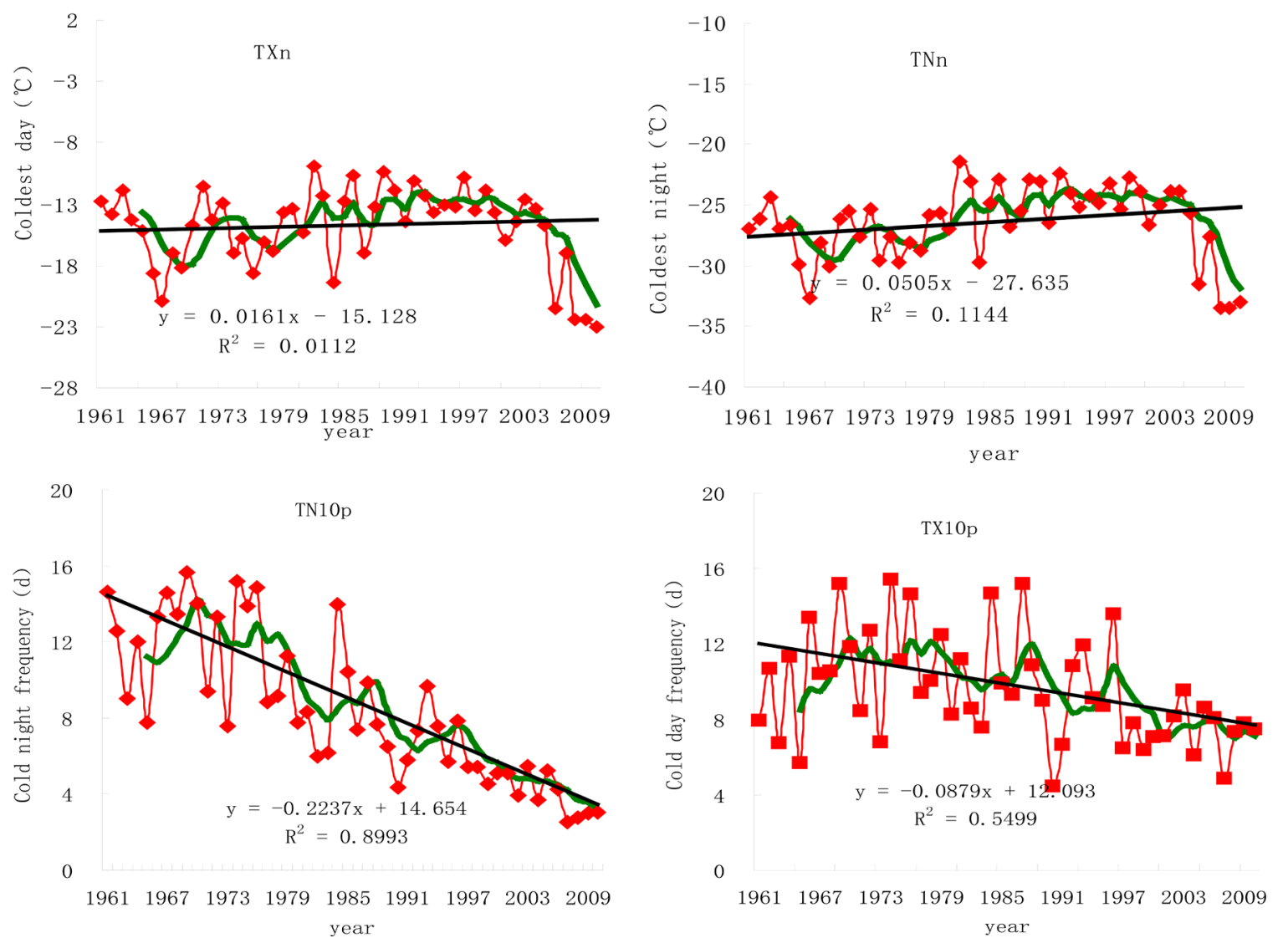

(Note: the straight line means linear fitting trend line, the smooth curve is moving average value in 5 years, attached mark is actual test value)

Figure 2. Regional annual anomalies series during 1961-2010 for indices of cold extremes. 
Table 3. The extreme temperature mean value $\left({ }^{\circ} \mathrm{C}\right.$ or $\mathrm{d}$ ) and change range $\left.\left[{ }^{\circ} \mathrm{C} / 10 \mathrm{a}\right) / \mathrm{or} \mathrm{d} /(10 \mathrm{a})\right]$.

\begin{tabular}{|c|c|c|c|c|c|c|c|c|}
\hline \multirow{2}{*}{ Index } & \multirow{2}{*}{$\begin{array}{l}\text { Standard } \\
\text { difference }\end{array}$} & \multirow{2}{*}{$\begin{array}{l}\text { Change } \\
\text { tendency } \\
\text { rate }\end{array}$} & \multicolumn{6}{|c|}{ Average value } \\
\hline & & & Over the years & The 1960s & The 1970s & The 1980s & The $1990 \mathrm{~s}$ & From the year of 2000s \\
\hline FD & 10.05 & 4.8 & 162.64 & 169.88 & 167.47 & 166.69 & 162.18 & 146.78 \\
\hline ID & 8.85 & 2.75 & 68.799 & 72.07 & 73.8 & 69.3 & 67.8 & 60.9 \\
\hline TXn & 3.29 & 0.16 & -14.917 & -15.8 & -15 & -13.3 & -12.8 & -17.8 \\
\hline TNn & 3.01 & 0.505 & -26.504 & -27.8 & -27.4 & -24.7 & -24.2 & -28.4 \\
\hline TN10 & 3.88 & 2.237 & 8.44 & 12.7 & 11.1 & 8.1 & 6.4 & 3.9 \\
\hline TX10 & 2.81 & 0.879 & 9.54 & 10.4 & 10.9 & 10 & 8.9 & 7.5 \\
\hline
\end{tabular}

The monthly maximum temperature minimum value (TXn) and monthly extreme minimum temperature (TNn) showed increasing trends, with interannual variation tendency rates of $0.16^{\circ} \mathrm{C} / 10 \mathrm{a}$ and $0.505^{\circ} \mathrm{C} / 10 \mathrm{a}$, respectively, although these trends were not significant $(\alpha>0.05)$. The correlation coefficients of TXn and TNn by year were -0.133 and 0.042 , indicating significant warming, especially on low-temperature days, the frequency of which has decreased over time.

\subsection{Spatial Variation in Extreme Cold Events}

Against the background of global warming, the extreme cold indices generally showed decreasing trends over the past 50 years, but changes in these indices were characterized by spatial variation (Figure 3). Change tendency rates of continuous FD ranged from -7.8 to $-2.0 \mathrm{~d} / 10 \mathrm{a}$ and displayed significant decreasing trends at about $91.4 \%$ of all stations (only $2.8 \%$ of stations showed increasing trends or no obvious trend). Variation tendency rates for IDs ranged from -4.0 to $-1.5 \mathrm{~d} / 10 \mathrm{a}$, and were $<0$ at $80 \%$ of stations. Thus, the ID data showed significant decreasing trends in most regions, all of which were in northern Xinjiang.

Variation tendency rates for TN10p ranged from -3.7 to $-0 \mathrm{~d} / 10 \mathrm{a}$ and were $<0$ at $88.5 \%$ of stations; however, the decreasing trends were not significant. The rates for TX10p ranged from -1.3 to $-0.5 \mathrm{~d} / 10 \mathrm{a}$ and were $<0$ at $48.5 \%$ of stations; these declining trends were significant. The variation tendency rates for TXn ranged from 0.04 to $2.5^{\circ} \mathrm{C} / 10 \mathrm{a}$ and exceeded 0 at $48.5 \%$ of stations; increasing trends were significant at $37.5 \%$ of stations. Variation tendency rates for $\mathrm{TNn}$ ranged from 0 to $2.5^{\circ} \mathrm{C} / 10 \mathrm{a}$ and showed obvious increasing trends at $94.2 \%$ of stations.

\subsection{Interannual Variation in Extreme Warm Events}

For the past 50 years, all extreme warm event indices, such as the numbers of summertime days (SU25), warmnighttime days (TN90p), and warm-daytime days (TX90p), as well as monthly extreme maximum temperature (TXx) and the monthly minimum temperature maximal value (TNx), showed significant increasing trends in the Xinjiang area (Figure 4). The increasing rates for SU25, TN90p, and TX90p were 2.59, 3.38, and 1.59 d/10a, respectively (all $\alpha \leq 0.05$ ), with correlation coefficients by year of $0.48,0.86$, and 0.6 , respectively (all with $\geq 99 \%$ confidence). The variation tendency rates for $\mathrm{TXx}$ and $\mathrm{TNx}$ were $0.23^{\circ} \mathrm{C} / 10 \mathrm{a}$ and $0.52^{\circ} \mathrm{C} / 10 \mathrm{a}$, respectively, and the correlation coefficients by year were 0.36 and 0.64 , respectively (all $\alpha \leq 0.01$ ).

The graph of changes in day-by-day temperature range (DTR; Figure 3 \& Figure 4) shows a decreasing trend in Xinjiang over the past 50 years (rate, $\left.0.21^{\circ} \mathrm{C} / 10 \mathrm{a}\right)$, with a correlation coefficient by year of $-0.54(\alpha=0.01)$. The trend of change in extreme annual temperature range in the entire Xinjiang area complies with that throughout China [19].

\subsection{Spatial Variation in Extreme Warm Events}

Against the background of global warming, the extreme warm indices in the Xinjiang area generally showed increasing trends over the past 50 years, but these changes were characterized by spatial variation (Figure 5). Variation tendency rates for SU25 ranged from0 to $8.0 \mathrm{~d} / 10 \mathrm{a}$, and about $100 \%$ of stations showed significant increasing trends. The variation tendency rates for TN90p ranged from -0.2 to $8.0 \mathrm{~d} / 10 \mathrm{a}$, and $62.8 \%$ of stations showed significant increasing trends. The variation tendency rates for TX90p ranged from 0.2 to $3.2 \mathrm{~d} / 10 \mathrm{a}$ and exceeded 0 at $91 \%$ of stations, with $80 \%$ of stations showing significant trends. The variation tendency rates for 
TXx ranged from -0.24 to $0.9^{\circ} \mathrm{C} / 10 \mathrm{a}$ and exceeded 0 at $77.1 \%$ of stations, with very significant increasing trends at $59.2 \%$ of stations. The variation tendency rates for $\mathrm{TNx}$ ranged from -1.86 to $3.0^{\circ} \mathrm{C} / 10 \mathrm{a}$ and exceeded 0 at $82.8 \%$ of stations. Trends of increasing TNx were very significant at $58.6 \%$ of stations.

Although the ranges of increase in variation tendency rates for TXn and TNn exceeded those for TXx and TNx, all stations showed decreasing trends for DTR.
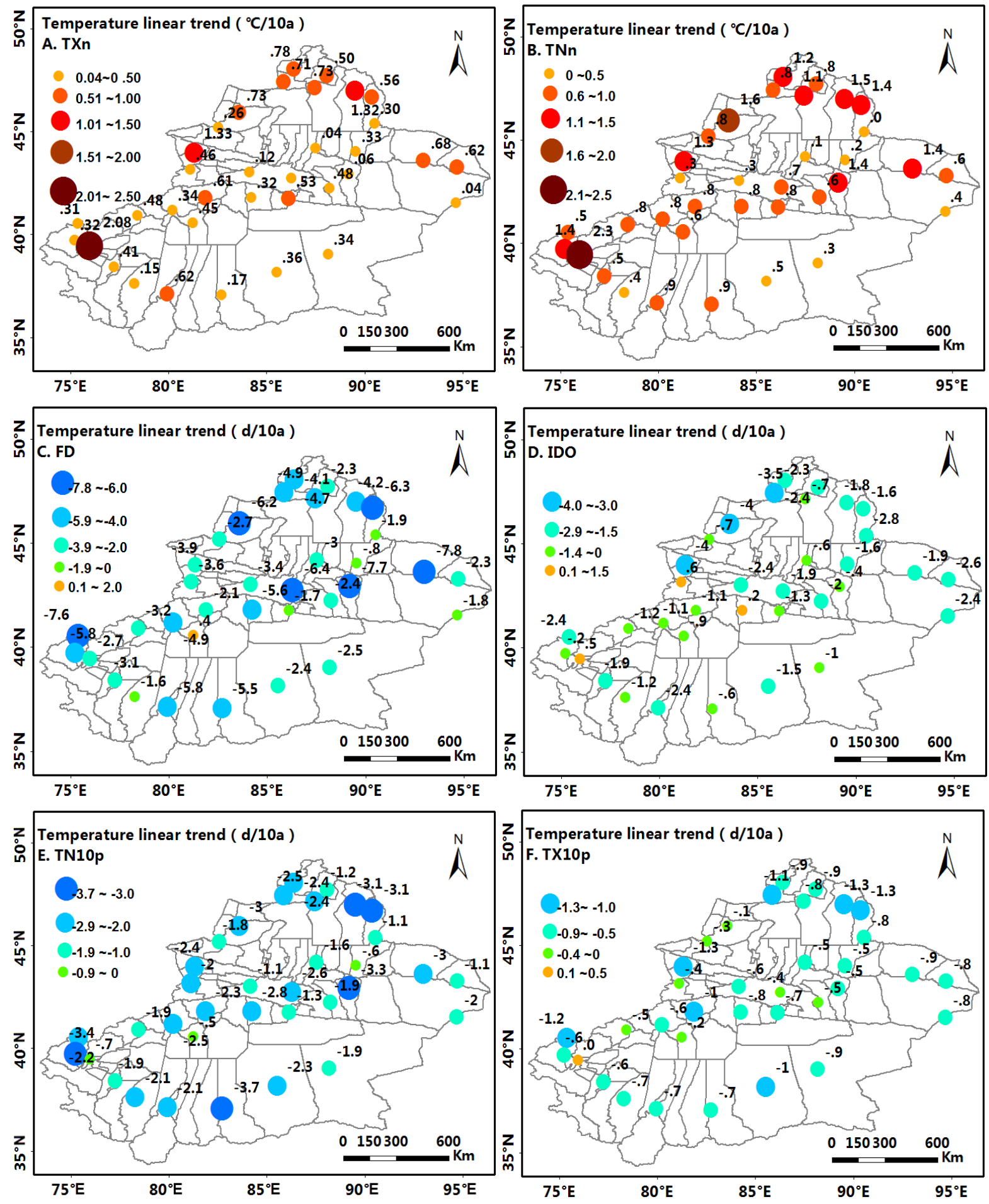

Figure 3. Spatial distribution of linear tendency rate for indices of cold extremes during 1961-2010. 


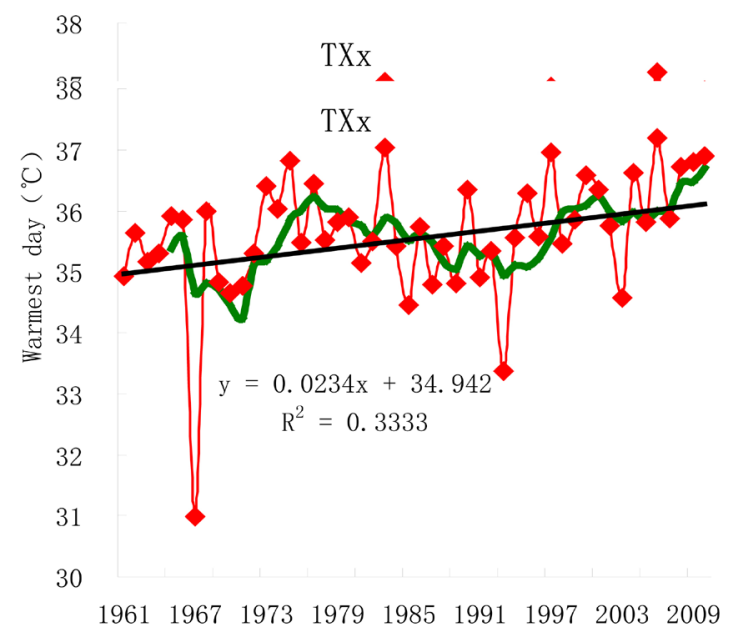
year

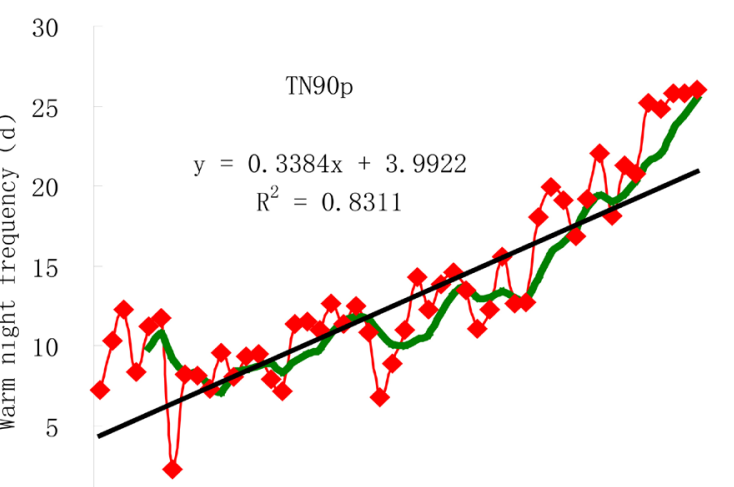

196119671973197919851991199720032009 year

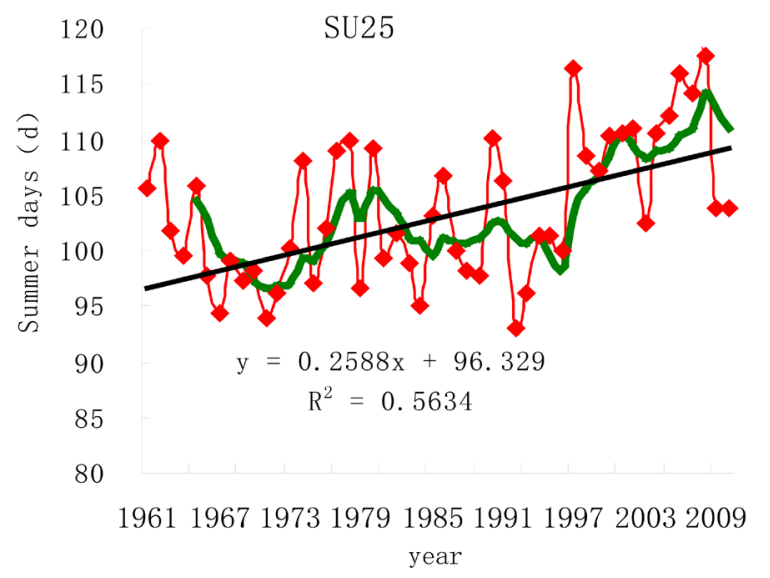

26

26

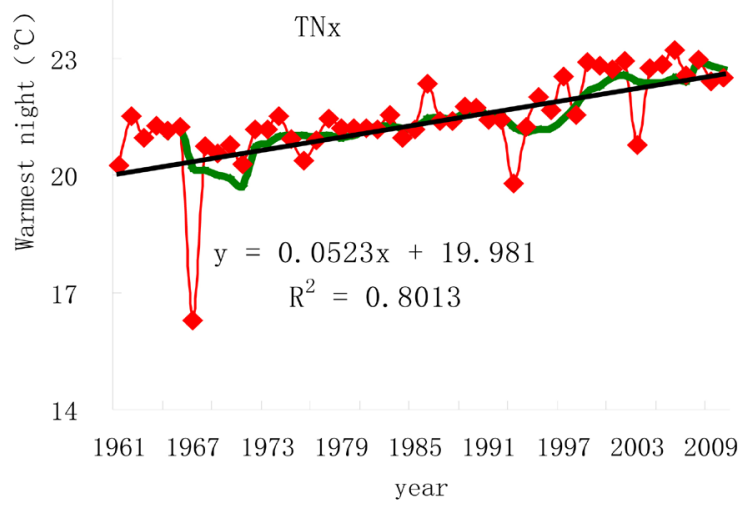

25

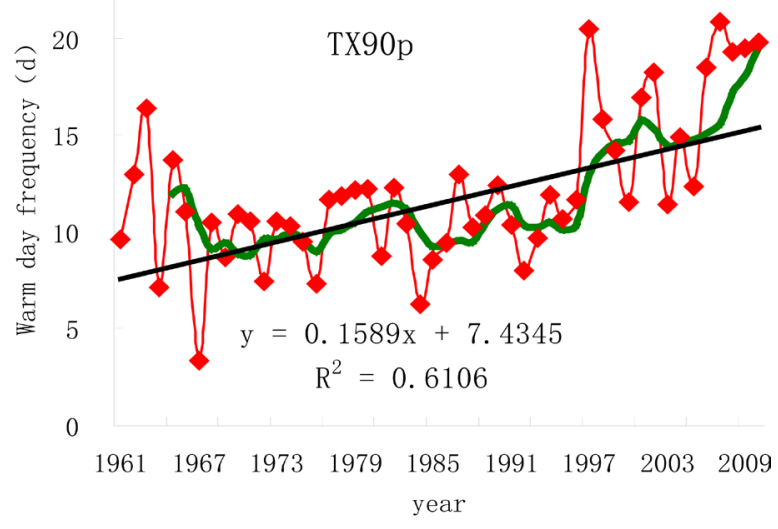

15

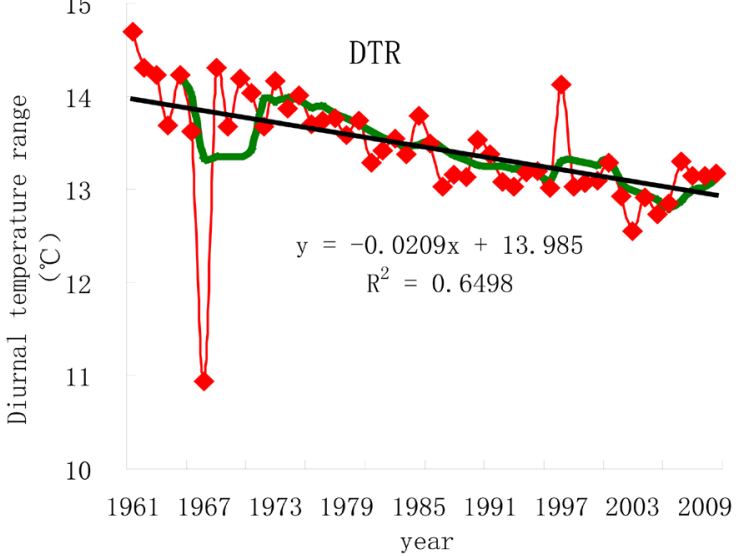

(Note: the straight line means linear fitting trend line, the smooth curve is moving average value in 5 years, attached mark is actual test value)

Figure 4. Regional annual anomalies series during 1961-2010 for indices of warm extremes.

\section{Changes in Extreme Precipitation Events in Xinjiang over the Past 50 Years}

\subsection{Interannual Variation Trends for Extreme Precipitation Indices}

Precipitation intensity is one factor used to measure extreme precipitation, with greater intensity associated with greater possibility of disaster. Average precipitation intensity in the Xinjiang area showed a predominant trend 
of annual increases over the past 50 years, consistent with global data and those for China [20]. However, the range of change indicated by the extreme precipitation intensity indices was small relative to those for extreme temperature events. Total precipitation during the wet season (PRCPTOT) in each year from 1961 to 2010 appeared to show a significant increasing trend (rate, $8.23 \mathrm{~mm} / 10 \mathrm{a} ; \alpha=0.05$; Figure 6 ). The correlation coefficient of PRCPTOT by year was $0.43(\alpha=0.01$; Table 4). Average PRCPTOT over the years was $144.33 \mathrm{~mm}$ (standard difference, 23.297). The difference between the two periods of 1961-1980 and after 1980 was very significant.
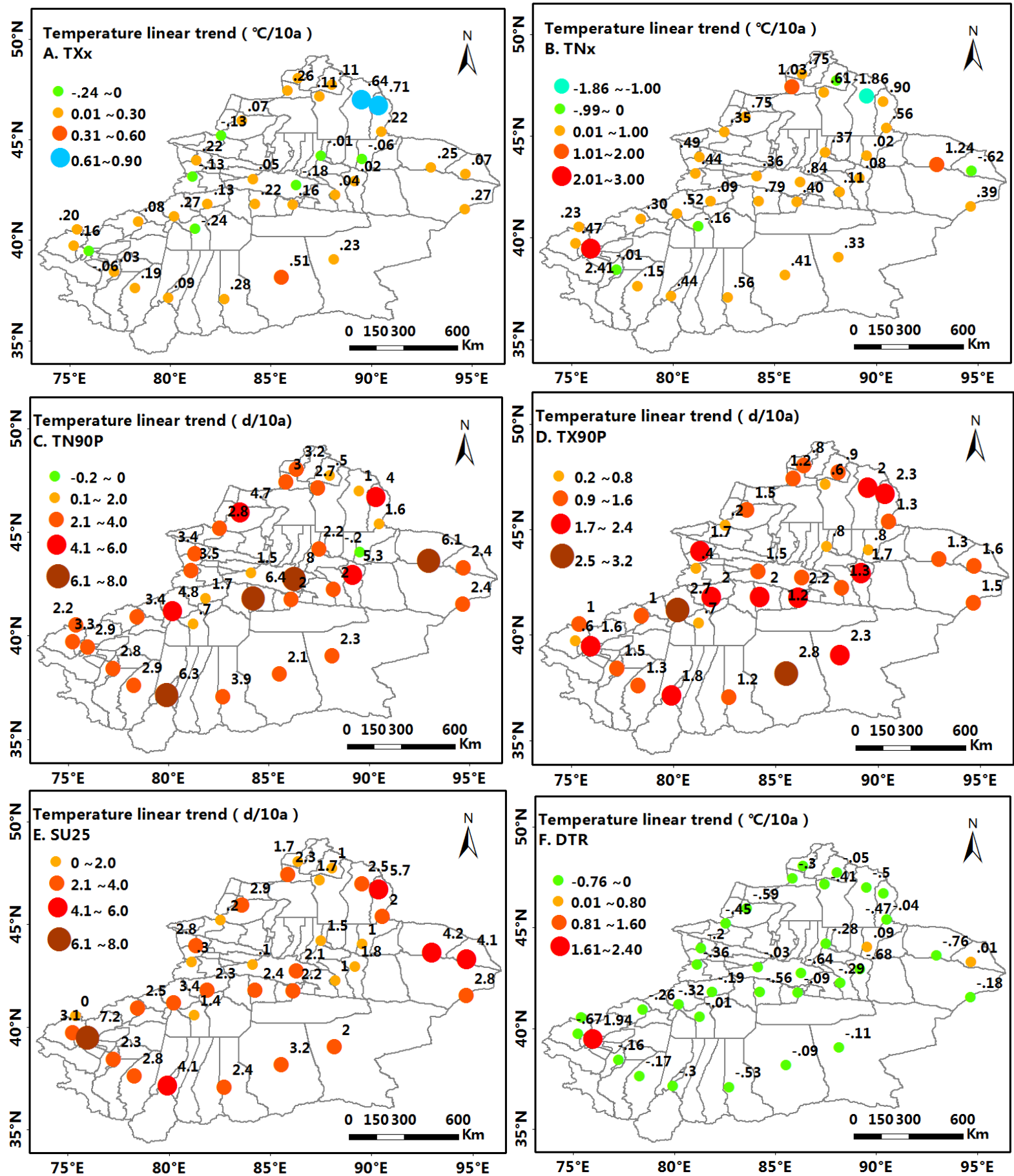

Figure 5. Spatial distribution of linear tendency rate for indices of warm extremes during 1961-2010. 

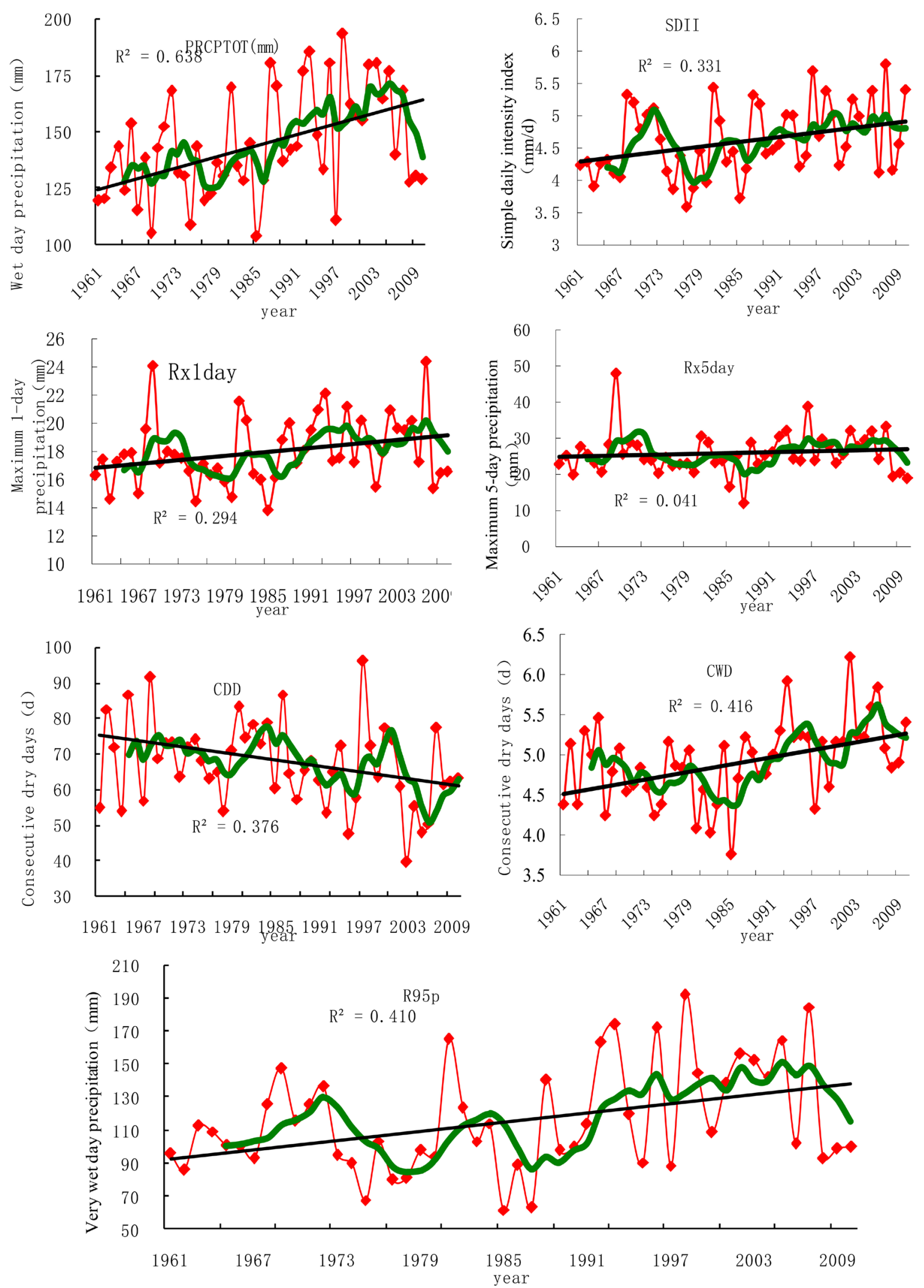

Note: the red dot means actual measure value, green line means moving average in 5 years, the straight line means simple regression trend line. Figure 6. Inter-annual variation of precipitation extremes in Xinjiang during 1961-2010. 
Table 4. The standard difference of extreme precipitation index and change tendency rate $(\mathrm{mm} / 10 \mathrm{a})$ and mean value (d or $\mathrm{mm}$ ) in Xinjiang.

\begin{tabular}{|c|c|c|c|c|c|c|c|c|}
\hline \multirow{2}{*}{ Index } & \multirow{2}{*}{$\begin{array}{l}\text { Standard } \\
\text { difference }\end{array}$} & \multirow{2}{*}{$\begin{array}{c}\text { Change } \\
\text { tendency } \\
\text { rate }\end{array}$} & \multicolumn{6}{|c|}{ Mean value } \\
\hline & & & Over the year & The 1960s & The 1970s & The 1980s & The 1990s & From the year of 2000s \\
\hline PRCPTOT & 23.297 & 8.232 & 144.33 & 129.38 & 134.16 & 143.79 & 159.22 & 155.11 \\
\hline SDII & 0.549 & 0.13 & 4.62 & 4.45 & 4.3 & 4.64 & 4.82 & 4.9 \\
\hline RX1day & 2.355 & 0.474 & 17.97 & 17.71 & 16.51 & 17.81 & 19 & 18.81 \\
\hline RX5day & 5.639 & 0.434 & 25.704 & 26.68 & 23.86 & 23.69 & 28.01 & 26.29 \\
\hline R95 & 32.197 & 9.322 & 116.24 & 108.56 & 97.1 & 105.65 & 136.7 & 133.2 \\
\hline CDD & 11.795 & -2.867 & 67.2 & 71.23 & 68.53 & 70.59 & 66.59 & 59.04 \\
\hline CWD & 0.49 & 0.154 & 4.92 & 4.83 & 4.67 & 4.63 & 5.11 & 5.35 \\
\hline
\end{tabular}

The simple precipitation intensity index (SDII) showed small increasing trend at a rate of $0.13 \mathrm{~mm} / 10 \mathrm{a}$, but this trend was not significant ( $\alpha>0.05$; Figure 6). The standard difference in the SDII was 0.549, the mean value was $4.62 \mathrm{~mm} / \mathrm{d}$, and the correlation coefficient by year was 0.356 , indicating that changes in the SDII were stable over the past 50 years (Table 4). All extreme precipitation indices, such as monthly maximum precipitation on 1 day (RX1day), monthly maximum precipitation in 5 days (RX5day), strong rainfall amount (R95), and number of consecutive wet days (CWDs), showed increasing trends; the rates of increase for the indices mentioned above were $0.47 \mathrm{~mm} / 10 \mathrm{a}, 0.43 \mathrm{~mm} / 10 \mathrm{a}, 9.32 \mathrm{~d} / 10 \mathrm{a}$, and $0.15 \mathrm{~d} / 10 \mathrm{a}$, respectively. Among these values, the increasing trends for R95 and CWDs were significant. The correlation coefficients by year for these indices were $0.25,0.06,0.35$, and 0.41 , respectively, with those of R95 and CWD reaching 95\% confidence. The number of consecutive dry days (CDDs) showed a decreasing trend (rate, $2.87 \mathrm{~d} / 10 \mathrm{a}$ ), with a correlation coefficient by year of $-0.29(\alpha=0.05)$.

\subsection{Spatial Distribution Pattern of Extreme Precipitation Indices}

Interannual variation tendencies for most extreme precipitation indices, with the exception of the CDD index, showed significant increasing trends at most stations in the Xinjiang area over the past 50 years (Figure 7). PRCPTOT showed decreasing trends at only $2.8 \%$ of the 35 stations from which data were analyzed; most stations showed increasing trends (range, -30.68 to $19.78 \mathrm{~mm} / 10 \mathrm{a}$ ). The rate of increase was greater in the Tianshan and northern Xinjiang areas. Only $17.1 \%$ of stations showed decreasing trends for SDII; $82.8 \%$ of stations showed increasing trends, and the rate of increase was greater at southern stations.

Increasing trends in the extreme precipitation indices of RX1day, RX5day, R95, and CWDs were found at 25 (71.4\%), 28 (80\%), 30 (85.7\%), and 29 (82.8\%) stations, respectively. More than 70\% of stations showed increasing trends for PRCPTOT, SDII, RX1day, RX5day, R95, and CWDs, indicating that the frequency of extreme precipitation trends is generally increasing in the Xinjiang area. Analysis of CDD data from 11 (31.4\%) stations in southern and northern Xinjiang revealed an increasing trend and demonstrated regional tendencies for increased numbers of disasters involving drought.

\section{Conclusions}

In this study, 12 extreme temperature indices and 5 extreme precipitation indices were used to examine temporal and spatial variation in climatic extremes in Xinjiang over the past 50 years. The main conclusions are described below.

1) Analysis of temporal changes revealed decreasing trends in extreme cold indices (i.e., obvious reductions in the number of severely cold days and extreme low-temperature events), consistent with global warming. Linear variation in extreme warm indices showed notable increasing trends. The trends for TX10p, TN10p, IDs, and FDs $(-0.88,-2.24,-2.75,-4.8 \mathrm{~d} / 10 \mathrm{a}$, respectively) decreased, whereas those for TX90p, TN90p, and SU25 (1.59, 3.38, and $2.59 \mathrm{~d} / 10 \mathrm{a}$, respectively) increased.

2) Analysis of temporal changes in extreme precipitation indices (except CDDs), such as RX1day, RX5day, R95, and CWD, as well as PRCPTOT, showed consistently increasing trends (rates of 0.474 mm/10a, 0.434 $\mathrm{mm} / 10 \mathrm{a}, 9.322 \mathrm{~d} / 10 \mathrm{a}, 0.154 \mathrm{~d} / 10 \mathrm{a}$, and $8.232 \mathrm{~mm} / 10 \mathrm{a}$, respectively). 
3) Differences in the spatial distributions of the indices were notable. The frequencies of extreme cold and extreme warm events decreased in southern Xinjiang. The spatial distribution of extreme precipitation also showed obvious regional differences, with the directionality of trends differing between mountainous and desert basin areas. The response to global warming has been more notable in northern than in southern Xinjiang. Global climatic change has altered the ecology of northern Xinjiang and increased the frequency of extreme climatic disasters.

4) Changes in extreme cold and warm indices, as well as those in nighttime and daytime indices, showed notable asymmetry: the warming ranges of the cold and nighttime indices exceeded those of the warm and daytime indices, respectively.
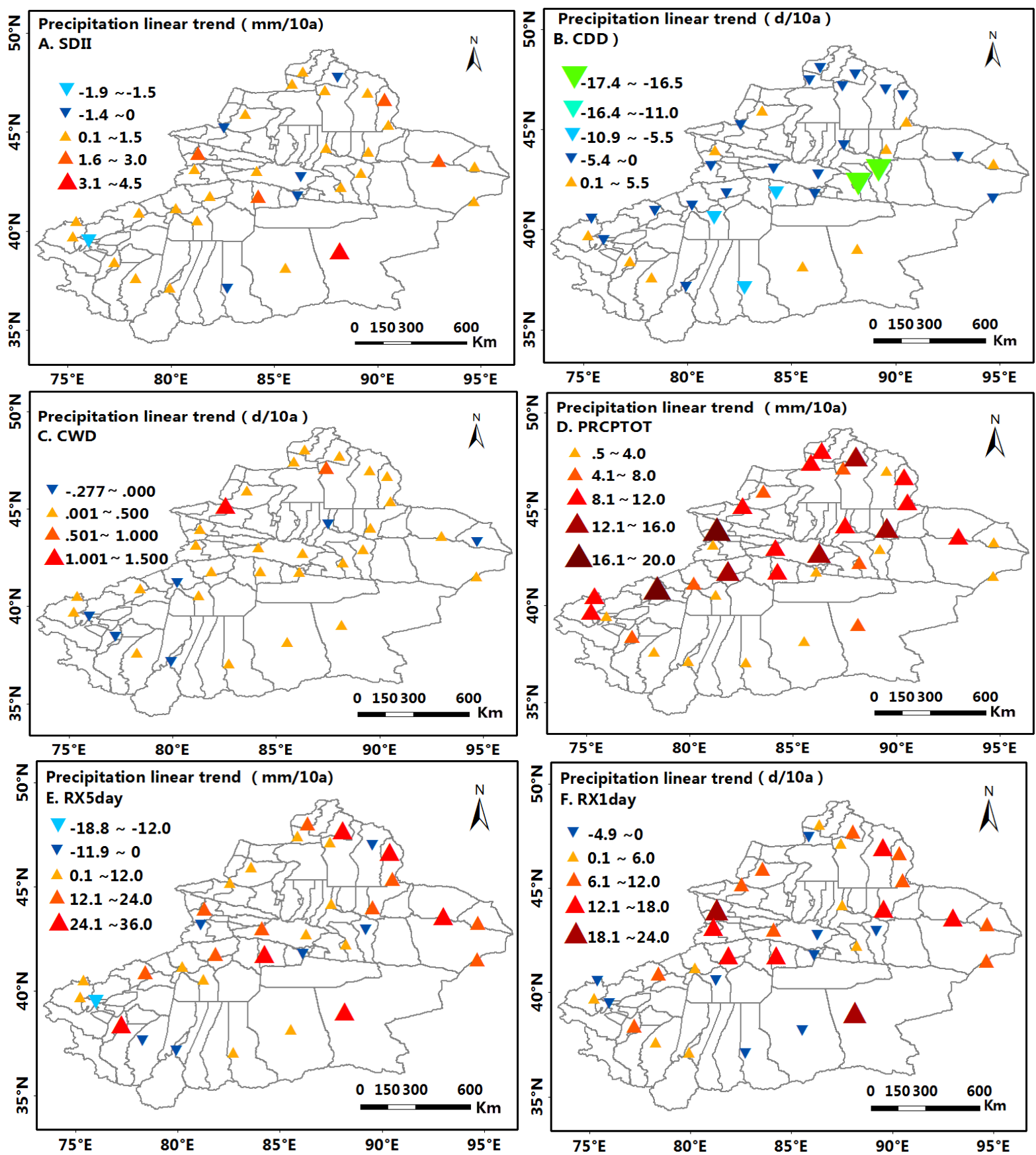

Figure 7. Spatial distribution of inter-annual variation of precipitation extremes in Xinjiang during 1961-2010. 


\section{Acknowledgements}

This study is jointly financed by the National Natural Science Fund Project (U1203282) and the National Natural Science Foundation Project of China (41001020), and the Xinjiang Uygur Autonomous Region Key Laboratory of “Xinjiang laboratory of Lake Environoments and Resources in Arid Zone” (XJDX0909-201212), the Shihezi University team innovation project (2014ZRKXJQ08). The authors gratefully acknowledge funding for this research and would like to express their sincere thanks to Zhang Yan Wei for the help with data.

\section{References}

[1] IPCC (2007) Climate Change 2007: The Physical Science Basis. Contribution of Working Group I to the Fourth Assessment Report of the Intergovernmental Panel on Climate Change. In: Solomon, S., Qin, D., Manninget, M., et al., Eds., Cambridge University Press, Cambridge, New York.

[2] Ren, G.Y., Guo, J., Xu, M.Z., et al. (2005) Nearly 50 Years Chinese Ground the Basic Characteristics of Climate Change. Journal of Meteorological, 942-956.

[3] Zhang, Y.W., Wei, W.S. and Jiang, F.Q. (2012) Trends of Extreme Precipitation Events over Xinjiang during 19612008. Journal of Mountain Science, 30, 417-424.

[4] Li, Z.X., He, Y.Q., Wang, C.F., et al. (2011) Spatial and Temporal Trends of Temperature and Precipitation during 1960-2008 at the Hengduan Mountains, China. Quaternary International, 236, 127-142. http://dx.doi.org/10.1016/j.quaint.2010.05.017

[5] Easterling, D.R., Gerald, A.M., Camille, P., et al. (2000) Climate Extremes: Observations, Modeling, and Impacts. Science, 289, 2068-2074. http://dx.doi.org/10.1126/science.289.5487.2068

[6] Ding, Y.H., Ren, Y.G., Shi, G.Y., et al. (2006) National Assessment Report of Climate Change (I): Climate Change in China and Its Future Trend. Advances in Climate Change Research, 2, 3-8.

[7] Yan, Z.W. and Yang, C. (2000) In Recent Decades Chinese Pattern of Extreme Climate Change. Journal of Climate and Environmental Research, 3, 267-272.

[8] Gao, X.J. (2007) Extreme Events Forecast Research in China. Research Progress on Climate Change, 3, 162-166.

[9] Zhang, S.J., Wang, T.M., Wang, T., et al. (2010) Xinjiang in Recent 50 Years Precipitation Temporal Variation and Mutation Analysis. Chinese Desert, 3, 668-674.

[10] Pu, Z.C. and Zhang, S.Q. (2011) 1961-2008, Heat-Humidity Climate Spatial Temporal Variation in Xinjiang Summer Half Year. Resource and Environment in Arid Area, 25, 138-144.

[11] Wang, S.J., Yang, L.M. and Shi, Y.G. (2012) 1991-2010 in Urumqi, Rainfall Characteristics Analysis. Chinese Desert, 11, 509-516.

[12] Yang, L.M. (2003) Climate Change of Extreme Precipitation in Xinjiang. Acta Geographica Sinica, 58, 577-583.

[13] Jiang, F.Q., Hu, R.J., Zhang, Y.W. and Li, X.M. (2011) Variations and Trends of Onset, Cessation and Length of Climatic Growing Season over Xinjiang, NW China. Theoretical and Applied Climatology, 106, 449-458. http://dx.doi.org/10.1007/s00704-011-0445-5

[14] Bai, L., Li, L.H., Li, Q., et al. (2012) Ralationship between Soil’s Seasonal Freezing Process and Daily. Journal of Glaciology and Geocryology, 34, 328-335.

[15] Peterson, T.C. Climate Change Indices. WMO Bulletin.

[16] Aguilar, E., Peterson, T.C., Ramirez Obando, P., et al. (2005) Changes in Precipitation and Temperature Extremes in Central America and Northern South America, 1961-2003. Journal of Geo-Physical Research, 110, D23107. http://dx.doi.org/10.1029/2005JD006119

[17] Zhang, Y.W., Wei, W.S., Jiang, F.Q., et al. (2012) Assessment of Change in Temperature and Precipitation over Xinjiang, China. Natural Hazards and Earth System Sciences, 12, 1327-1331. http://dx.doi.org/10.5194/nhess-12-1327-2012

[18] Alexander, L.V., Zhang, X., Peterson, T.C., et al. (2006) Global Observed Changes in Daily Climate Extremes of Temperature and Precipitation. Journal of Geophysical Research, 111, DO5109. http://dx.doi.org/10.1029/2005JD006290

[19] Wang, Q., Zhang, M.J., Wang, S.J., et al. (2013) Analysis of Extreme Temperature Events in Yangtze River Basin from 1962 to 2011. Journal of Geography, 12, 611-625.

[20] Zhang, Z.Y., Liu, L. and Tang, X.L. (2013) Tianshan Mountains in China Nearly 50 Years Precipitation Change Regional Differences and Mutation Characteristics. Journal of Resources and Environment in Arid Areas, 7, 85-90. 


\section{Submit or recommend next manuscript to SCIRP and we will provide best service for you:}

Accepting pre-submission inquiries through Email, Facebook, LinkedIn, Twitter, etc.

A wide selection of journals (inclusive of 9 subjects, more than 200 journals)

Providing 24-hour high-quality service

User-friendly online submission system

Fair and swift peer-review system

Efficient typesetting and proofreading procedure

Display of the result of downloads and visits, as well as the number of cited articles

Maximum dissemination of your research work

Submit your manuscript at: http://papersubmission.scirp.org/ 